\title{
Antioxidant and Antibacterial Activity of Yellow Wood (Coscinium fenestratum ) Fruits Peel from East Kalimantan
}

\section{Aktivitas Antioksidan dan Antibakteri Kulit Buah Kayu Kuning (Coscinium fenestratum) Asal Kalimantan Timur}

\author{
Paula Mariana Kustiawan $^{1 *}$, Arbainsyah $^{2,3}$, Irfan Muris Setiawan $^{4}$ \\ ${ }^{1}$ Faculty of Pharmacy, Universitas Muhammadiyah Kalimantan Timur, Samarinda, East Kalimantan, Indonesia \\ ${ }^{2}$ Enviromental Leadership Training Program (ELTI) Coordinator, Asia Program, Yale University, USA \\ ${ }^{3}$ Research and Development Center for Natural Resources Conservation Technology, Samboja, Kalimantan Timur \\ ${ }^{4}$ Fakultas Farmasi, Universitas Gadjah Mada, Yogyakarta \\ ${ }^{*}$ E-mail: pmk195@umkt.ac.id
}

Article Info:

Received: 2 September 2021

in revised form: 16 September 2021

Accepted: 8 Oktober 2021

Available Online: 10 Oktober 2021

Keywords:

Antioxidant

Antibacterial

Coscinium fenestratum

Fruits Peel

East Kalimantan

Corresponding Author:

Paula Mariana Kustiawan

Faculty of Pharmacy,

Universitas Muhammadiyah

Kalimantan Timur

Samarinda

75124

Indonesia

email:pmk195@umkt.ac.id

\section{ABSTRACT}

Background: Yellow wood (Coscinium fenestratum) is one of the typical forest plants of East Kalimantan. The hallmark of this plant is the roots, stems and the fruits pulp have a yellow color. There have been many studies on its use and potential in treating liver disease. However, there is limited research about the use of their fruits peel. Objectives: The purpose of this study was as an initial screening of the antioxidant and antibacterial activity from yellow wood (Coscinium fenestratum) fruits peel. Material and Methods: The yellow wood fruits peel was extracted using methanol to obtain the $\mathrm{MeOH}$ extract of their fruits peel. The DPPH test was carried out to determine its antioxidant activity (25,50 and $100 \mathrm{ppm})$. The agar well difusion method was carried out to determine its antibacterial activity. Phytochemical tests were also carried out to determined the secondary metabolites of that fruits peel. Results: The results of the phytochemical test showed that the fruits peel contained alkaloids, flavonoids, carbohydrates, and tannins, but there were no terpenoids or steroids. The fruits peel has an antioxidant activity (58\%) at $100 \mathrm{ppm}$ concentration. While the antibacterial test showed strong inhibition at $100 \mathrm{ppm}$ concentration on $S$. mutans, $S$. aureus, $P$. acne and E. coli bacteria. Conclusions: The fruits peel of the yellow wood has metabolite compounds that have strong antibacterial activity and medium antioxidant activity. 


\begin{abstract}
ABSTRAK
Latar Belakang: Kayu kuning (Coscinium fenestratum) merupakan salah satu tumbuhan hutan khas Kalimantan Timur. Ciri khas tumbuhan ini adalah di dalam akar, batang dan isi buahnya berwarna kuning. Sudah banyak penelitian tentang pemanfaatan dan potensinya dalam mengobati penyakit liver. Namun, masih sedikit penelitian tentang pemanfaatan kulit buah tumbuhan tersebut. Tujuan: Tujuan penelitian ini adalah sebagai skrining awal aktivitas antioksidan dan antibakteri dari kulit buat kayu kuning (Coscinium fenestratum). Metode: Kulit buah kayu kuning diekstrak menggunakan pelarut metanol untuk mendapatkan ekstrak $\mathrm{MeOH}$ kulit buah kayu kuning. Pengujian DPPH dilakukan untuk menskrining potensi antioksidannya (25, 50 dan $100 \mathrm{ppm})$. Metode difusi sumuran dilakukan untuk melihat potensi antibakterinya. Uji fitokimia juga dilakukan sebagai acuan metabolit sekunder yang berperan. Hasil: Hasil uji fitokimia menunjukkan bahwa kulit buah kayu kuning memiliki senyawa golongan alkaloid, flavanoid, karbohidrat, dan tanin, tetapi tidak terdapat senyawa terpenoid maupun steroid. Tumbuhan tersebut memiliki aktivitas antioksidan 58\% pada konsentrasi 100 ppm. Sedangkan uji antibakteri menunjukan potensi penghambatan pada konsentrasi $100 \mathrm{ppm}$ pada bakteri S. mutans, S. aureus, P.acne dan E.coli dengan kategori kuat. Kesimpulan: Kulit buah kayu kuning memiliki senyawa yang memiliki aktivitas antibakteri yang tergolong kuat dan aktivitas antioksidan yang tergolong medium.
\end{abstract}

Kata kunci: Antioksidan; Antibakteri; Coscinium fenestratum; Kulit buah; Kalimantan Timur.

\title{
INTRODUCTION
}

Yellow wood is one of forest biodiversity that has been used by the Dayak and Banjar ethnic as traditional medicine. Arcangelicia flava, Fibraurea tinctoria and Coscinium fenestratum are there species of yellow wood were known originated from East Kalimantan (Sulistiarini, Soemardji, and Iwo 2020). These species have specific characteristic in the root and the wood has yellow color. That species was used by people as antigrastistic, antihepatotoxic (Fikriah 2012) and antimalaria (Hidayat, Rosidah, and Arryati 2020; Kusuma 2011; Noorcahyati 2012).

Coscinium fenestratum is plant species from family Menispermaceae was catagorized as endagered species in East Kalimantan (Danapur, Haleshi, and Sringeswara 2020). The stem and root of $C$. fenestratum was traditionally used as medicinal purpose for treating diabetes mellitus, microbial, inflammation, has antioxidants and another diseaseses. The extract of the stem was used as snake-bites treatment and fevers (Rai, Rajesh, and Kim 2013). The stem of $C$. fenestratum has asntibacterial activity againts S. aureus and Streptococcus pyogenes (Zalizar et al. 2019). This plant also have potential to stimulated immune system to prevent COVID-19 (Maharani and Fernandes 2021) and anti hypertensive (Jough, Saini, and Parveen 2021; Wongcome et al. 2007). Secondary metabolites of $C$. fenestratum was dominanted with alkaloid, steroid and saponin. Berberine was one of potential compound from $C$. fenestratum stem (Taher et al. 2019).

Fruit pulp of $C$. fenestratum also have antioxidant, and anthelmintic activity (Kuntal, Raman, and Sivaraman 2018). But the information of C. fenestratum fruits peel bioactivities are still limited. Then, the purpose of this study is to identify secondary metabolite of $C$. fenstratum fruits peel and its potential as antioxidant and antibacterial activity from East Kalimantan. 


\section{MATERIAL AND METHODS}

\section{Materials}

The fruits of Coscinium fenestratum was collected from Samboja Research Forest, Balikpapan City, East Kalimantan Province. Herbarium of plant was determinated in Samboja Herbarium Center and identify as Coscinium fenestratum. The main material that used in research are DMSO, DPPH (2,2difenil-1-pikrilhidrazil) (Sigma Aldrich), ascorbic acid, Staphylococcus aureus, Streptococcus mutans, Propionibacterium acnes, and Escherichia coli was cultured at Laboratory of Non-Timber Forest Product, Mulawarman University, nutrient agar media, cholarmphenicol, acetone (Merck), methanol (CV. Mulawarman Medika), methanol (analytical grade) (Sigma Aldrich).

\section{Methods}

\section{Extraction}

The fruits were separated between their pulp and peel (Figure 1.), then collected the peel for appropiate amount. The fruits peel was conducted to sortation and cleaned from remain pulp.
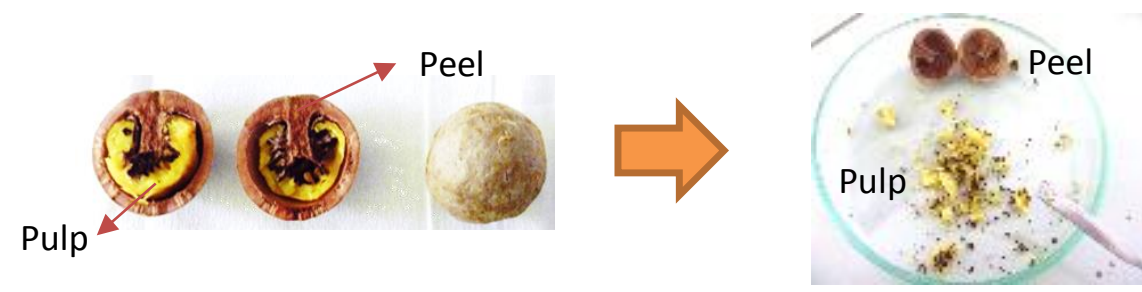

Figure 1. Separation between pulp and peel of Coscinium fenestratumfruits

It has been washed clean are made simplicia by drying in the sun. Those peel was crushed into small particle, then 200 grams of that was extracted with methanol solvent peel at room temperature ( 24 hours) to obtain $\mathrm{MeOH}$ extract of Coscinium fenestratum fruits. The filtrat was collected and remaceration 2 times. The filtrat was evaporated and obtained $\mathrm{MeOH}$ extract of $C$. fenestratum fruits peel. The yield obtained was calculated using the equation:

Yield: Extract weight (g)/weight of dried sample $(g) \times 100 \%$

\section{Phytochemical assay}

Secondary metabolites of $C$. fenestratum fruits peel were identified by using modifications methods of Harbone (1987) and Kokate (2001).

\section{Alkaloids}

A total of $5 \mathrm{~mL}$ of the extract was added with $2 \mathrm{~mL}$ of concentrated hydrochloric acid, followed by the addition of $1 \mathrm{~mL}$ of Dragendroff's reagent. The color of the solution will turn red or orange, indicating that the extract is positive for alkaloids. 
Flavonoids

The $1 \mathrm{~mL}$ of the extract was added a few drops of $1 \% \mathrm{NaOH}$, the solution had a bright yellow color, then $1 \% \mathrm{HCl}$ was added. The solution turned colorless, indicating a positive extract containing flavonoids.

Saponins

A total of $2 \mathrm{~mL}$ of the extract was put into the tube, then $10 \mathrm{~mL}$ of distilled water was added. The solution was shaken for 1 minute. The formation of stable foam indicated that the extract contained positive saponins.

Tannins

The tannin test was carried out by inserting $10 \mathrm{ml}$ of the extract into a test tube and adding $1 \%$ $\left(\mathrm{CH}_{3} \mathrm{COOH}\right)_{2} \mathrm{~Pb}$ solution if a yellow precipitate formed indicating the presence of tannins.

Terpenoids

Testing of triterpenoids and steroids using Liebermann-Burchard reagents, the 10 drops of acetic anhydride and 2 drops of concentrated sulfuric acid were added to $1 \mathrm{ml}$ of extract, if the color of the sample changed to red and purple, it indicated the presence of triterpenoids.

Carbohydrate

Carbohydrate testing was carried out by adding 1 drop of Molisch reagent into $1 \mathrm{ml}$ of extract then through the wall of the test tube added $1 \mathrm{ml}$ of concentrated sulfuric acid, if a purple ring formed between the 2 layers indicates the presence of carbohydrates.

\section{Antioxidant Assay}

Antioxidant assay was carried out using the DPPH method (Kuspradini et al. 2016). The concentrations of the samples used were 25, 50 and $100 \mathrm{ug} / \mathrm{mL}$. Vitamin C was used as a positive control. Fruits peel extract of $C$. fenestratum was dissolved with DMSO and $33 \mu 1$ was taken into the tube. Then mixed into the solution as much as $467 \mu \mathrm{l}$ of ethanol. $500 \mu \mathrm{l}$ of DPPH was added to the solution and incubated for 20 minutes in the dark. After that, the absorbance was measured using UV/Vis 1200 spectrophotometry with a wavelength of $514 \mathrm{~nm}$. The percentage value of antioxidant inhibition was calculated using the equation: 
$\%$ inhibition $=($ Absorption control - Sample absorbance $) /$ Absorption control $\times 100 \%$

\section{Antibacterial Assay}

This assay was used disc diffusion method (Kusuma et al, 2013) with nutrient agar as media for bacteria culture. Methanol extracts of $C$. fenestratum fruits peel were dissolved in acetone to obtain a concentration of 25,50 , and $100 \mu \mathrm{g} / \mathrm{mL}$ (ppm), with the concentration of standard drugs used were 10 $\mu \mathrm{g} / \mathrm{disk}$. Four species of bacteria was used, such as Streptococcus mutans, Staphylococcus aureus, Propionibacterium acne and Escherichia coli. Inhibition zones on the discs were measured in milli meters (mm). Antimicrobial activity was calculated by the mean inhibition zone for the standard.

\section{Data Analysis}

Data analysis was carried out by calculating the average value of three repetitions using Microsoft Excel 2016.

\section{RESULTS AND DISCUSSION}

The extraction process from $200 \mathrm{~g}$ fruits peel of $C$. fenestratum obtained $11.25 \mathrm{~g}$ methanol extract and yield 39,18\% (Table 1.) Methanol solvent will attract compounds that are relatively polar. Phenolic compounds and glycosides are most likely to be extracted in these solvents.

Table 1. The yield of Coscinium fenestratum fruits peel

\begin{tabular}{ccc}
\hline Weight of dried fruits peel $(\mathrm{g})$ & Weight of $\mathrm{MeOH}$ Extract $(\mathrm{g})$ & Yield $(\%)$ \\
\hline 200 & 78,36 & 39,18 \\
\hline
\end{tabular}

The methanol extract of $C$. fenestratum fruits peel was used to determine antioxidant and antibacterial activity.

\section{Phytochemical results}

The methanol extract of Coscinium fenestratum fruits peel was continued with qualitative phytochemical tests to identify these secondary metabolites. Based on the results, the content of secondary metabolites is shown in Table 2 .

Table 2. The secondary metabolite of Coscinium fenestratum fruits peel

\begin{tabular}{ccc}
\hline Secondary metabolite & Indicator & Results \\
\hline Alkaloid & Orange color & + \\
Flavanoid & Colorless & + \\
Saponin & Foam performance & + \\
\hline
\end{tabular}




\begin{tabular}{ccc} 
Terpenoid & No color change & - \\
Carbohydrate & Purple ring between the 2 layers & + \\
Tanin & Yellow precipitation & + \\
\hline
\end{tabular}

This result have similarities in secondary metabolites in stem of C. fenestratum from Malinau Regency which also contain alkaloid, steroid and saponin (Rahayu, Sutedjo, and Matius 2007). Although obtained from different part and locations, dominan metabolite was the same.

Alkaloid and flavanoid are common plant metabolite with important biological properties and can be utilized for pharmaceutical purposes (Roy 2017). The potential bioactivity from this secondary metabolite such as antibacterial, antioxidant and anticancer (Alibi, Crespo, and Navas 2021; Hidalgo, Sánchez-Moreno, and de Pascual-Teresa 2010; Yun et al. 2021)

Antioxidant activity

The DPPH method was used to determine the antioxidant activity of the methanolic extract of $C$. fenestratum fruits peel because it is relatively simple, sensitive and requires a small number of samples. (Molyneux 2004). The result showed the methanolic extract of $C$. fenestratum fruits peel had antioxidant activity in medium catagorize with free radical inhibition $58 \%$ at $100 \mathrm{ppm}$ concentration (Figure 2).

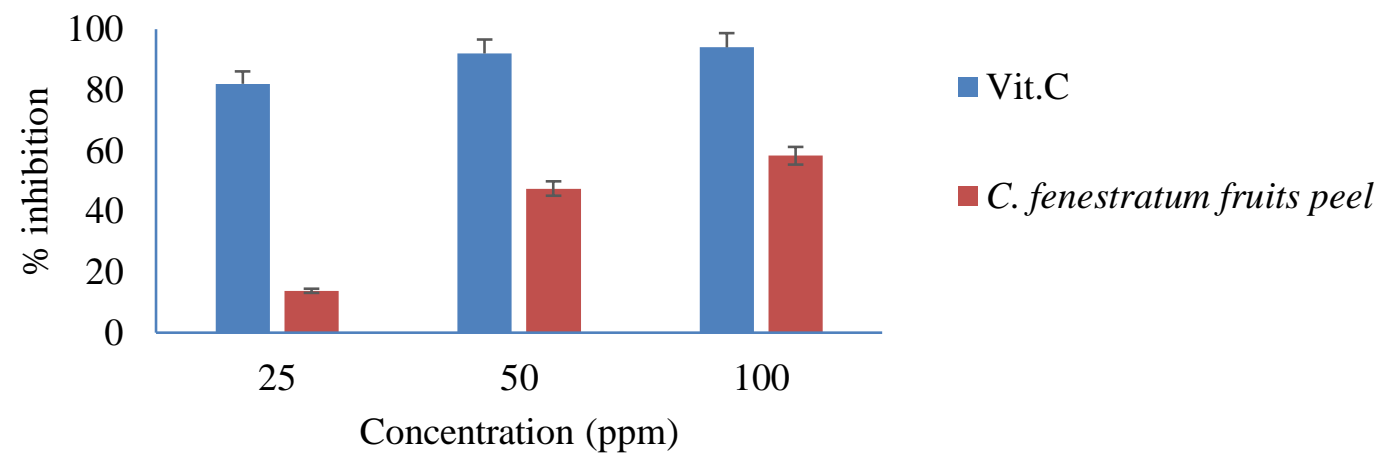

Figure 2. Percentage of free radical inhibition from Coscinium fenestratum fruits peel.

Another study showed that the antioxidant activity of the methanol extract of $C$. fenestratum stem (256 $\mu \mathrm{g} / \mathrm{ml})$ and leaves $(512 \mu \mathrm{g} / \mathrm{ml})$ had inhibition $71.3 \pm 0.36 \%$ and $49 \pm 0.88 \%$ (Goveas and Abraham 2013). However, Berberine, one of the pure compounds found from $C$. fenestratum stem, had strong antioxidant activity. The antioxidant activity of $C$. fenestratum stem also have important mechanism in imunomodulatory activity (Kothalawala et al. 2020). The methanol extract was better for Berberine extraction from the female $C$. fenestratum flowers and also showed higher antioxidant activity (Roopashree et al. 2021). The presence of alkaloid in C. fenestratum fruits peel, could be indicated by berbirine as antioxidant agent (Neethu et al. 2014). 


\section{Antibacterial activity}

The antibacterial assay againts 4 bacteria were conducted to determine Coscinium fenestratum fruit peel activity. The result showed that at concentration $100 \mathrm{ppm}, C$. fenestratum fruit peel had maximum zone inhibition antibacterial activity against $P$. acne $(15,06 \pm 1,08 \mathrm{~mm})$, respectively (Table 3 .). These catagorized as strong antibacterial activity (Davis and Stout 1971)

Table 3. The inhibition zone of antibacterial activity of Coscinium fenestratum fruits peel

\begin{tabular}{cccccc}
\hline \multirow{2}{*}{$\begin{array}{c}\text { Concentration } \\
(\mathrm{ppm})\end{array}$} & \multicolumn{5}{c}{ Inhibition zone $(\mathrm{mm})$} \\
\cline { 2 - 5 } & S. mutan & S. aureus & P. acne & E.coli & Catagorize \\
\hline 25 & $5,51 \pm 1,51$ & $6,34 \pm 0,37$ & $7,11 \pm 1,25$ & $5,24 \pm 0,54$ & Medium \\
50 & $7,13 \pm 0,43$ & $8,52 \pm 0,78$ & $8,97 \pm 0,79$ & $7,98 \pm 0,66$ & Medium \\
100 & $12,02 \pm 0,98$ & $13,2 \pm 0,92$ & $15,06 \pm 1,08$ & $14,63 \pm 0.97$ & Strong \\
$(+)$ & $20,56 \pm 1,70$ & $21,01 \pm 0,59$ & $18,90 \pm 1,55$ & $17,32 \pm 1,37$ & Strong \\
\hline
\end{tabular}

This result was comparable with antibacterial activity of $C$. fenestratum methanol extract from India, the stem showed maximum antibacterial activity against $E$. coli $(17 \pm 0.33 \mathrm{~mm})$ and the leaveas extract had maximum zone of inhibition for S. aureus $(6.4 \pm 0.67 \mathrm{~mm})$ (Goveas and Abraham 2013). Antibacterial activity also examinated with another researcher and also showed high potential activity in stem (Nair et al. 2005). These finding showed not only stem and leaves, but also fruits peel of $C$. fenestratum has antibacterial activities.

The secondary metabolite in C. fenestratum fruits peel have important rules in antioxidant and antibacterial activities. Such as, nitrogen atom that contained on alkaloid structure has specific pathway in antibacterial activity through enzyme inhibition, cell division intervention, respiratory inhibition, membrane disruption and affecting virulence genes of bacteria (Radulovic et al. 2013; Vaou et al. 2021). Further research is needed to explore the pure compound in fruits peel to proving the effectiveness of these compound on antioxidant and antibacterial activities.

\section{CONCLUSION}

The fruits peel of the yellow wood has metabolite compounds that have strong antibacterial activity and medium antioxidant activity.

\section{ACKNOWLEDGEMENT}

Thanks to the member in Laboratory of Chemistry of Non-Timber Forest Products, Faculty of Forestry, Mulawarman University for the research support facilities and Kaltim Cemerlang Scholarship, East Kalimantan Province. The authors wish would acknowledge to Lisnawaty Manullang, the alumni and technician who involved in this research. 


\section{CONFLICT OF INTEREST}

All authors declared no conflict of interest.

\section{REFERENCES}

Alibi, S., D. Crespo, and J. Navas. 2021. "Plant-Derivatives Small Molecules with Antibacterial Activity." Antibiotics 10(3):231.

Danapur, V., C. Haleshi, and A. N. Sringeswara. 2020. "Endangered Medicinal Plant Coscinium Fenestratum (Gaertn.) Colebr A Review. , 12(5).” Pharmacognosy Journal 12(5).

Davis, W. W., and T. R. Stout. 1971. "Disc Plate Methods of Microbiological Antibiotic Assay." Pp. 659-65 in Microbiology. Vol. 22.

Fikriah, I. 2012. “Aktivitas Hepatoprotektor Batang Fibraure Tinctoria Lour Secara In Vivo.” J. Trop. Pharm. Chem. 1(4):289-94.

Goveas, S. W., and A. S. H. A. Abraham. 2013. "Evaluation of Antimicrobial and Antioxidant Activity of Stem and Leaf Extracts of Coscinium Fenestratum.” Asian J Pharm Clin Res 6(3):218-21.

Hidalgo, M., C. Sánchez-Moreno, and S. de Pascual-Teresa. 2010. "Flavonoid-Flavonoid Interaction and Its Effect on Their Antioxidant Activity." Food Chemistry 121(3):691-96.

Hidayat, M., Rosidah, and H. Arryati. 2020. "Ethnobotany Medicinal Plant of the of Dayak Bakumpai Tribe in Lemo II Village Central Teweh District North Barito Regency.” Jurnal Sylva Scienteae 3(4):687-98.

Jough, S. S., R. K. Saini, and A. Parveen. 2021. "A Comprehensive Study on Anti-Hypertensive Properties of Punica Granatum (Pomegranate), Cynara Scolymus (Artichoke), Coscinium Fenestratum (Yellow Vine) in Phytopharmacological, Molecular Biology Researches." Asian Journal of Research in Pharmaceutical Science 11(2).

Kothalawala, S. D., D. Edward, J. C. Harasgama, L. Ranaweera, O. V. D. S. J. Weerasena, R. Niloofa, and S. M. Handunnetti. 2020. "Immunomodulatory Activity of a Traditional Sri Lankan Concoction of Coriandrum Sativum L. and Coscinium Fenestratum G." Evidence-Based Complementary and Alternative Medicine.

Kuntal, D. A. S., D. A. N. G. Raman, and R. P. E. G. Sivaraman. 2018. "Phytochemical Screening for Various Secondary Metabolites, Antioxidant, and Anthelmintic Activity of Coscinium Fenestratum Fruit Pulp: A New Biosource for Novel Drug Discovery." Turkish Journal of 
Pharmaceutical Sciences 15(2):156.

Kuspradini, H., A. S. Putri, E. Sukaton, and T. Mitsunaga. 2016. "Bioactivity of Essential Oils from Leaves of Dryobalanops Lanceolata, Cinnamomum Burmannii, Cananga Odorata, and Scorodocarpus Borneensis.” Agriculture and Agricultural Science Procedia (9):411-18.

Kusuma, P. K. G. T. 2011. "Uji Efektifitas Akar Kayu Kuning (Coscinium Fenestratum Colebr) Sebagai Antimalaria Pada Mencit Yang Diinfeksi Plasmodium Berghei.” Institute Pertanian Bogor.

Maharani, R., and A. Fernandes. 2021. "The Potential of Herbal Medicine from Kalimantan, Indonesia, to Stimulate Human Immunity during the COVID-19 Pandemic: A Brief Overview." Annals of Phytomedicine-an International Journal S115-20.

Molyneux, P. 2004. "The Use of the Stable Free Radical Diphenylpicryl-Hydrazyl (DPPH) for Estimating Antioxidant Activity." Songklanakarin J. Sci. Technol 26(2):211-19.

Nair, G. M., S. Narasimhan, S. Shiburaj, and T. K. Abraham. 2005. "Antibacterial Effects of Coscinium Fenestratum.” Fitoterapia 76(6):585-87.

Neethu, P., P. R. S. T. Haseena, R. S. Thomas, S. W. Goveas, and A. Abraham. 2014. "Antioxidant Properties of Coscinium Fenestratum Stem Extracts on Streptozotocin Induced Type 1 Diabetic Rats.” J Appl Pharm Sci 4(1):29-32.

Noorcahyati. 2012. Tumbuhan Berkhasiat Obat Asal Kalimantan. Balikpapan, East Kalimantan: Center for Natural Resources Conservation Technology.

Radulovic, N. S., P. D. Blagojevic, Z. Z. Stojanovic-Radic, and N. M. Stojanovic. 2013. “Antimicrobial Plant Metabolites: Structural Diversity and Mechanism of Action.” Current Medicinal Chemistry 20(7):932-52.

Rahayu, Y. D., Sutedjo, and P. Matius. 2007. "Studies on Potential of the Medicinal Plants in Malinau Research Forest Area (MRF) Cifor, Malinau Regency, East Kalimantan.” Jurnal Kehutanan Unmul 3(1):87-101.

Rai, R. V., P. S. Rajesh, and H. M. Kim. 2013. "Medicinal Use of $<\mathrm{i}>$ Coscinium Fenestratum $</ \mathrm{i}$ ) (Gaertn.) Colebr.: An Short Review.” Oriental Pharmacy and Experimental Medicine 13(1):1-9.

Roopashree, T. S., D. Kuntal, N. Prashanth, and K. R. Kumar. 2021. "Pharmacognostic and Chromatographic Evaluation of Male and Female Flowers of Coscinium Fenestratum for Berberine Content and Its Effect on Antioxidant Activity." Thai Journal of Pharmaceutical 
Sciences 45(2).

Roy, Arpita. 2017. "A Review on the Alkaloids an Important Therapeutic Compound from Plants." International Journal of Plant Biotechnology 3(2):1-7.

Sulistiarini, R., A. A. Soemardji, and M. I. Iwo. 2020. "Pharmacological Activities of Three Kinds 'Kayu Kuning': Arcangelisia Flava, Fibraurea Tinctoria, and Coscinium Fenestratum-an Short Review." Journal of Tropical Pharmacy and Chemistry 5(2):150-56.

Taher, M., M. S. Amri, D. Susanti, M. B. A. Kudos, A. N. Shafawi, and S. N. Yazid. 2019. “Taher, M., Amri, M. S., Susanti, D., Kudos, M. B. A., Shafawi, A. N., \& Yazid, S. N. Coscinium Fenestratum: A Review on Phytochemicals and Pharmacological Properties." Pp. 107-25 in Natural Bio-active Compounds.

Vaou, N., E. Stavropoulou, C. Voidarou, C. Tsigalou, and E. Bezirtzoglou. 2021. "Towards Advances in Medicinal Plant Antimicrobial Activity: A Review Study on Challenges and Future Perspectives." Microorganisms 9(10):2041.

Wongcome, T., A. Panthong, S. Jesadanont, D. Kanjanapothi, T. Taesotikul, and N. Lertprasertsuke. 2007. "Hypotensive Effect and Toxicology of the Extract from Coscinium Fenestratum (Gaertn.) Colebr." Journal of Ethnopharmacology 111(3):468-75.

Yun, D., S. Y. Yoon, S. J. Park, and Y. J. Park. 2021. “The Anticancer Effect of Natural Plant Alkaloid Isoquinolines.” International Journal of Molecular Sciences 22(4):1653.

Zalizar, I., I. D. Rahayu, Sujono, and Y. A. Nor. 2019. "Potency of Fibraurea Tinctoria Lour. Extract as Anti-Bacterial Agents towards Pathogenic Bacteria." IOP Conf. Series: Earth Environ Sci 293(012016). 